\title{
Synthesis ,spectroscopic study of Antipyryl azo 2-Naphthol and use it as new reagent for determination of $\mathrm{Co}(\mathrm{II})$ and $\mathrm{Cu}(\mathrm{II})$
}

\author{
Hussain.J. Mohammed* \\ Fatema. Abbas** \\ Received 25 ,November ,2012 \\ Accepted 9, December, 2012
}

\begin{abstract}
A simple ,accurate and sensitive spectrophotometric method has been developed the determination of Cobalt(II) and Cupper (II) .The method is based on the chelation of $\mathrm{Co}(\mathrm{II})$ and $\mathrm{Cu}$ (II) ions with 4-(4'-pyrazolon azo) -2-Naphthol(APAN) in aqueous medium. The complexes have a maximum absorption at (513) and (506) $\mathrm{nm}$ and $\varepsilon$ ${ }_{\max } 0.531 \times 10^{4}$ and $0.12 \times 10^{5} \mathrm{~L} \cdot \mathrm{mol}^{-1} . \mathrm{cm}^{-1}$ for $\mathrm{Co}$ (II) and $\mathrm{Cu}(\mathrm{II})$ respectively .The reagent and two complexes have been prepared in ethanolic solution.The stoichiometry of both complexes were found to be 1:2 (metal :legend).The effects of various cations and anions on $\mathrm{Co}(\mathrm{II})$ and $\mathrm{Cu}(\mathrm{II})$ determination have been investigated .The stability constants and standard deviations for $\mathrm{Co}(\mathrm{II})$ and $\mathrm{Cu}$ (II) $0.291 \times 10^{7}$ $, 0.909 \times 10^{8} \mathrm{~L} \mathrm{~mol}^{-1},(0.291)$ and $(0.332)$ respectively .The optimum condition for full color development for described methods were applied satisfactorily to synthetic samples.
\end{abstract}

Key Word:- Copper (II), Cobalt (II), determination, spectrophotometry , antipyriyl azo -2-Naphthol.

\section{Introduction:}

Pyrazolne moiety ( a five- membered lactam ring alternatively a derivative of pyrazole possessing an additional carbonyl /hydroxyl group )[1].Metal complexes of azo compounds containing hetero aryl ring systems find various applications .These type of molecules have several advantages ,for example the azo group is photo cromic ,redox responsive,stability low valent metal oxidation states due to the presence of a low -lying azo centered $\pi^{*}$ molecular or bital serves as a molecular switch is used as ametal ion indicator ,dyes and pigments in industry [2].Copper is anutitionally essential metal and is widely distributed in nature, Cobalt is an important essential micronutrient for all living systems [3]. As well as these two ions were studied by many researchers [4]'estimated by these two ions in the samples biologic and environmental[5].At present, a lot of analytical methods have been proposed for the determination copper (II) and cobalt (II) ,inductively coupled plasma mass spectrometry (ICPMass)[6,7],and atomic absorption spectrometry (AAS)[8,9] ,Show good sensitivity but is limited because of expensive instrumentation and high cost for routine analysis .According to the best of our knowledge ,this reagent has not been reported in the literature as being used for any cation determination. In this method 4-(4ロantipyriyl azo)-2-Naphthol has been used as a reagent for the spectrophotometric determination

\footnotetext{
* Faculty of ScienceChemistry Departmen t University of kufa

**Faculty of Education for Women University of kufa
} 
$\mathrm{Cu}$ (II) and $\mathrm{Co}$ (II), The present method has been found to be simple, rapid and sensitive for the determination of these metal ions

\section{Experimental Part}

\section{All chemical used were of analytical} grade

\section{A- Preparation of reagent (APAN)}

The reagent was prepared by coupling 2-naphthol with 4-amino antipyrin diazotate in alkaline alcoholic solution. A diazonium solution was prepared by taking $1.0 \mathrm{~g}, 0.004 \mathrm{~mol} \mathrm{4-}$ amino antipyrin in $25 \mathrm{ml}$ of ethanol and $5 \mathrm{ml}$ concentrated hydrochloric acid with $15 \mathrm{ml}$ of distilled water , and adding sodium nitrite solution dropwise at $0-5 \circ \mathrm{C}^{\circ}, 2$-Napthol 0.0083 mol $1.2 \mathrm{~g}$ was dissolved in $50 \mathrm{ml}$ of ethanol and $35 \mathrm{ml}$ of $(4 \mathrm{~N}) \mathrm{NaOH}$ were added at $\left(0-5 \mathrm{C}^{\circ}\right)$. The mixture was allowed to stand and added $20 \% \mathrm{HCl}$ solution .The precipitate was filtered off and recrystallized from ethanol [10] scheme 1.

Scheme 1. Preparation of reagent APAN

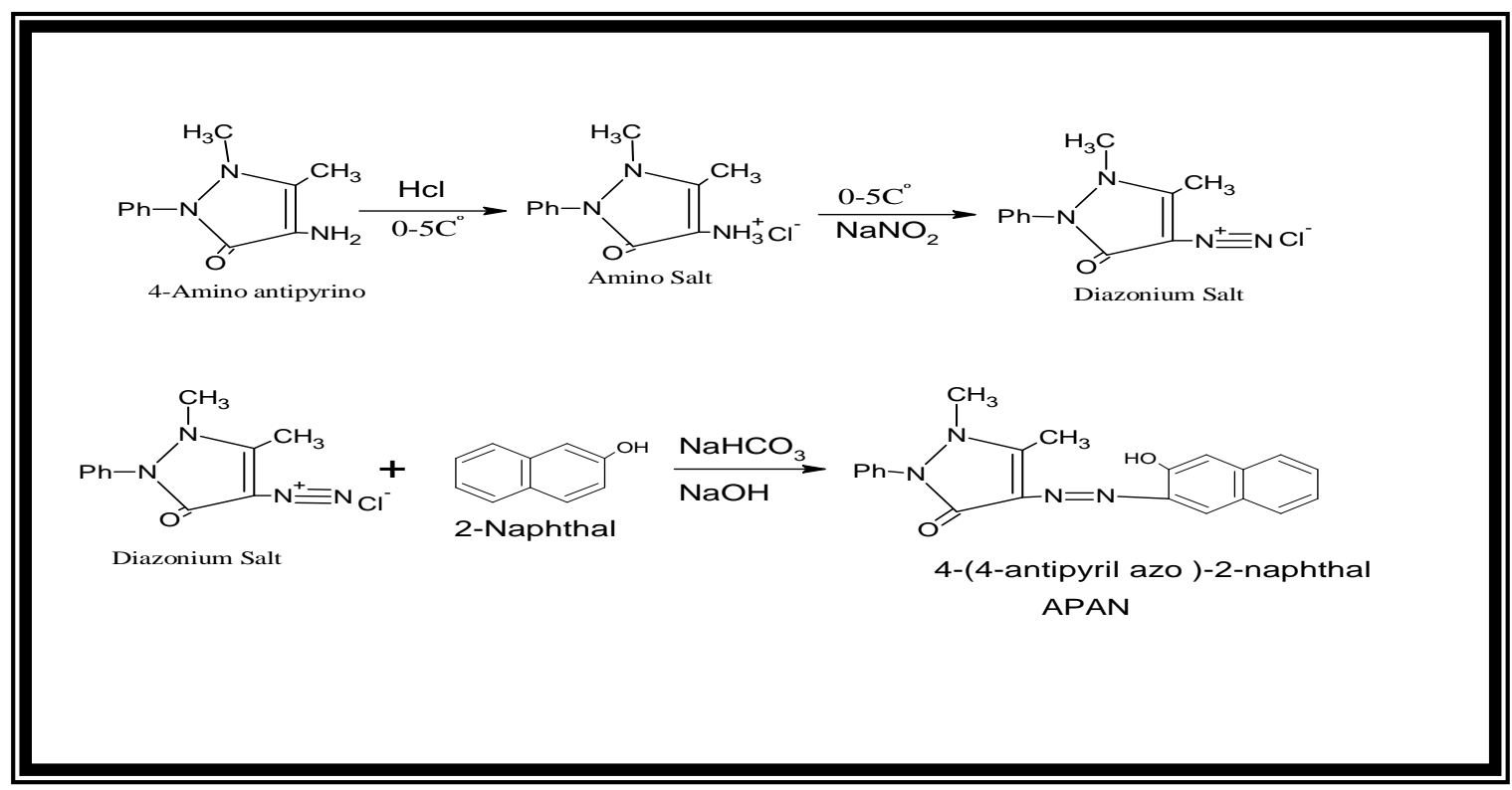

\section{B- preparation of complex}

The complex was prepared by stoichiometric amount from ligand in $50 \mathrm{ml}$ of ethanol then added drop wise with stirring to a stoichiometric amount 1:2 ions(cupper,coblet) in (25) $\mathrm{ml}$ hot distilled water. The solid product thus formed off, washed with ethanol and dried

\section{Apparatus}

Spectrophotometric measurements were made with shimadzu UV-Visible -1700 double beam spectrophotometer using (1.0) $\mathrm{cm}$ glass cell .The $\mathrm{pH}$ measurements were performed with AWTW pH -meter 720 . Electric molar conductivity measurements were carried out at room temperature using an Alpha digital conductivity model 800 .Vibration spectra were recorded in Testscan Shimadzu FT.IR 8000 series .

\section{Reagents}

All chemicals used were of analytical reagent grade

\section{Cupper (II) stock solution (100 $\left.\mu g . m l^{-1}\right)$}


Dissolve $0.0268 \mathrm{gm}$ of $\mathrm{CuCl}_{2} \cdot \mathrm{H}_{2} \mathrm{O}$ in $100 \mathrm{ml}$ of distilled water ,working standard $\mathrm{Cu}$ (II) solution were prepared by dilution of the appropriate volume of standard $\mathrm{Cu}$ (II) solution $(10 \mu \mathrm{g} / \mathrm{ml})$ with distilled water

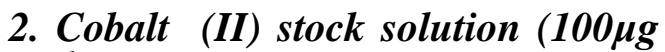 $m l^{-1}$ )}

Dissolve $0.02203 \mathrm{gm}$ of $\mathrm{CoCl}_{2}$ in $100 \mathrm{ml}$ of distilled water, working standard Co (II) solution were prepared by dilution of the appropriate volume of standard $\mathrm{Co}(\mathrm{II})$ solution $(10 \mu \mathrm{g} / \mathrm{ml})$ with distilled water .

\section{4-(4- antipyriyl azo ) -2-}

$\operatorname{Naphtol}\left(1 \times 10^{-3} \mathrm{M}\right)$

$0.0358 \mathrm{gm}$ of regent (APAN) was dissolved in $100 \mathrm{ml}$ of ethanol working(APAN) $\left(1 \times 10^{-3} \mathrm{M}\right)$ solution was prepared by simple dilution of appropriate volume of the reagent solution with ethanol.

\section{Foreign ion solutions (100 $\mu \mathrm{g} \mathrm{ml^{-1 } )}$}

These solutions were prepared by dissolving an amount of the compound in distilled water completing the volume in a volumetric flask.

\section{General procedure}

In to a series of $10 \mathrm{ml}$ calibrated flask, transfer increasing volumes of $\mathrm{Co}$ (II) and $\mathrm{Cu}(\mathrm{II})$ working solution $10 \mu \mathrm{g} \cdot \mathrm{ml}^{-1}$ to cover the range of calibration curve ,add $3.5 \mathrm{ml}$ and $2.5 \mathrm{ml}$ of $5 \times 10^{-4} \mathrm{M}$ of(APAN) solution and $\mathrm{PH}$ was adjusted to 3 and 9 by buffer solution from ammonium acetate (0.01) for $\mathrm{Cu}(\mathrm{II})$ and $\mathrm{Co}(\mathrm{II})$ respectively .Measure the absorbance at $513 \mathrm{~nm}$, for $\mathrm{Co}(\mathrm{II})$ and at $506 \mathrm{~nm}$ for $\mathrm{Cu}$ (II) for against blank prepared in the same way but containing no $\mathrm{Co}$ (II) or $\mathrm{Cu}$ (II) respectively. The color of the complexes is stable for $24 \mathrm{hrs}$.

Table (1): The characteristics of two complexes with APAN reagent

\begin{tabular}{|c|c|c|}
\hline Characteristic & Co(II) & Cu(II) \\
\hline Absorption maxime $(\mathrm{nm})$ & $513 \mathrm{~nm}$ & $506 \mathrm{~nm}$ \\
\hline Beer's law range $(\mu \mathrm{g} / \mathrm{ml})$ & $0.2-2.4$ & $0.2-2$ \\
\hline $\mathrm{pH}$ range & $5.5-9.5$ & $2.5-4.5$ \\
\hline $\begin{array}{c}\text { Sandell } \text { S sensitivity } \\
\mu \mathrm{g} . \mathrm{cm}^{-2}\end{array}$ & $0.005 \mu \mathrm{g} . \mathrm{cm}^{-2}$ & $0.0018 \mu \mathrm{g} . \mathrm{cm}^{-2}$ \\
\hline $\begin{array}{c}\text { Molar absorptivity } \\
\left(\text { L.mole }^{-1} . \mathrm{cm}^{-1}\right)\end{array}$ & $0.531 \times 10^{4}$ & $0.12 \times 10^{5}$ \\
\hline${\text { Stability constant }\left(\mathrm{L} . \mathrm{mol}^{-1}\right)}^{\mathrm{K}_{\mathrm{f}}}$ & $0.291 \times 10^{7}$ & $9.09 \times 10^{8}$ \\
\hline$\Delta{\mathrm{G} \mathrm{KJ} . \mathrm{mole}^{-1}}^{-1}$ & $0.14 \times 10^{2}$ & $0.74 \times 10^{2}$ \\
\hline
\end{tabular}

\section{Results and Discussion:}

Properties of (APAN) and its metal chelate

APAN is a tridentate with coordination of azo group nitrogen, hydroxyl group and carbonyl group ; it has the following structure

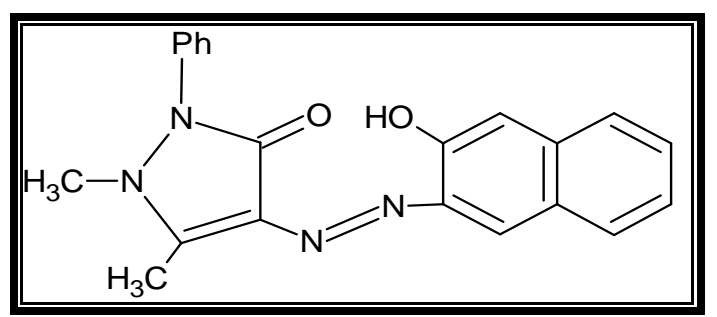

Structure of APAN 
Owing to the large conjugated system , the compound showed excellent chelating ability to form metal chelates . APAN and their metals chelates can be easily solubilized in an aqueous solutions

\section{Spectra}

The results of this work indicated that the reactions of $\mathrm{Co}$ (II) and $\mathrm{Cu}$ (II) with APAR at pH 9 and 3 yield highly soluble products which can be utilized as a suitable assay procedures for Co (II) and $\mathrm{Cu}$ (II) respectively . These products have a maximum absorption at $513 \mathrm{~nm}$ and at $506 \mathrm{~nm}$ at which the blank at these wave lengths shows zero absorbance Fig. 1,2 .The effect of various parameters on the absorbance intensity of the formed products were studied and the reactions conditions were optimized .

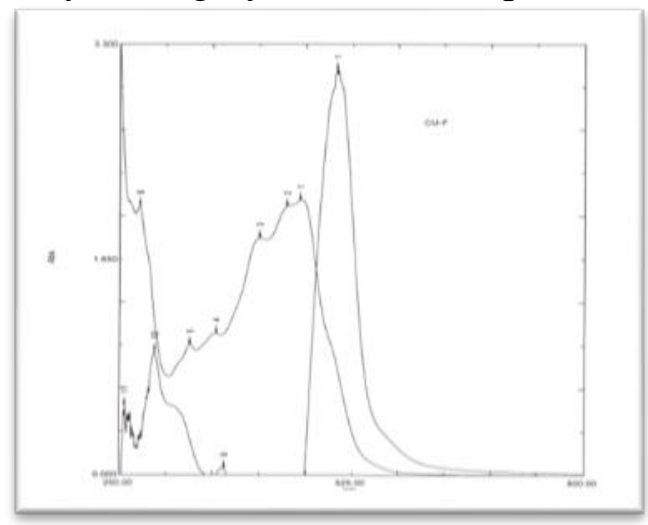

Fig (1). Absorption spectra of (APAN-Cu) treated as described under procedures and measured against a reagent blank and $R$ the reagent blank against ethanol

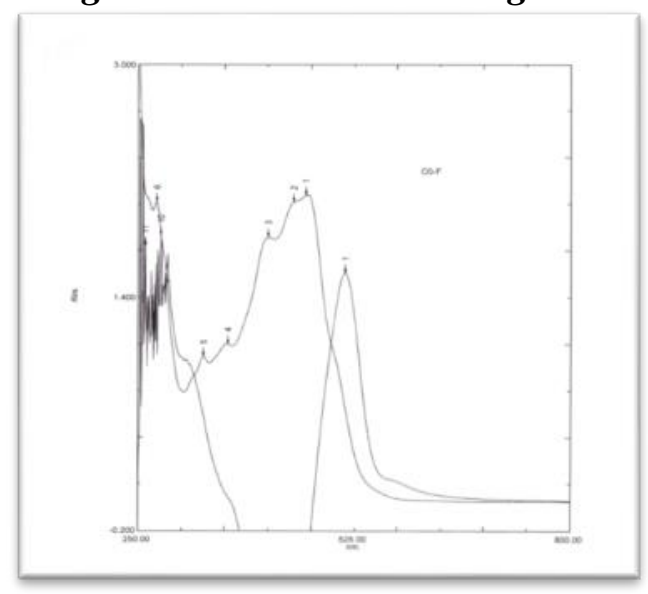

Fig (2).Absorption spectra of (APAN-Co) treated as described under procedures and measured against a reagent blank and $R$ the reagent blank against ethanol. Effect of (APAN) concentration

Various concentrations of $4-(4$ antipyriyl azo)-2- Naphtol were added to fixed concentration of Co (II) and $\mathrm{Cu}(\mathrm{II}): 3.5 \mathrm{ml}$ and $2.5 \mathrm{ml}$ of $1 \times 10^{-4} \mathrm{M}$ (APAN) solution was sufficient and gave minimum blank value and were consider to be optimum for the concentrating range . Therefore $3.5 \mathrm{ml}$ and 2.5 of $1 \times 10^{-4} \mathrm{M}$ of(APAN) were used in all subsequent experiment Fig 3. 


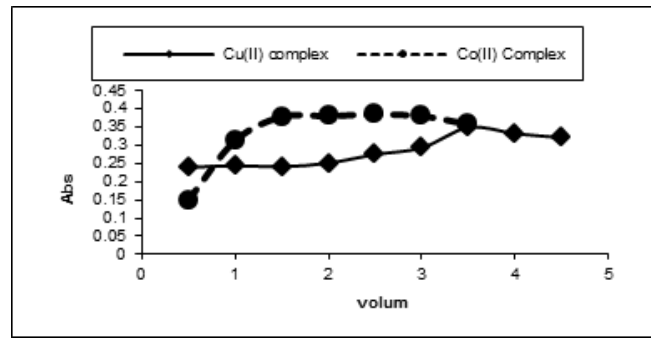

Fig( 3). Effect of concentration

\section{Effect of $p H$}

The electronic absorption of APAN and their complexes in ethanol have been recorded in the wavelength range (200 - 465) nm Fig. 1.2 . The electronic absorption of complex Co(II) showed a red shift for) electronic transition band charge transfer . [ $\mathrm{Co}(\mathrm{L}) . \mathrm{H}_{2} \mathrm{O}$ ] shows one broad in visible region at $60.70 \mathrm{~cm}^{-1}$ refer to ${ }^{4} \mathrm{~T}_{1 \mathrm{~g}}(\mathrm{~F}) \stackrel{{ }^{2}}{\longrightarrow} \mathrm{T}_{1 \mathrm{~g}}(\mathrm{~F})$ that is in accordance with tetrahedral geometry of cobalt metal ion[11]. The $\mathrm{pH}$ of metal complex solutions was adjusted using dilute solutions $(0.01 \quad \mathrm{M})$ $\mathrm{CH}_{3} \mathrm{COONa}$, and the effect on absorbance was studied Fig.4 . The absorbance of the complex was maximum and constant in the $\mathrm{pH}$ range given in Table. 1 whereas, The complex of $\left[\mathrm{Cu}(\mathrm{L})_{2}\right] \mathrm{H}_{2} \mathrm{O}$ shows bands appearing in the rang of 250 $373 \mathrm{~nm}$ attributed to $\pi \longrightarrow \pi^{*}$ transition. The other bands observed in the region of $373-506 \mathrm{~nm}$ is attributed charge transfer to electronic transition Fig 4.

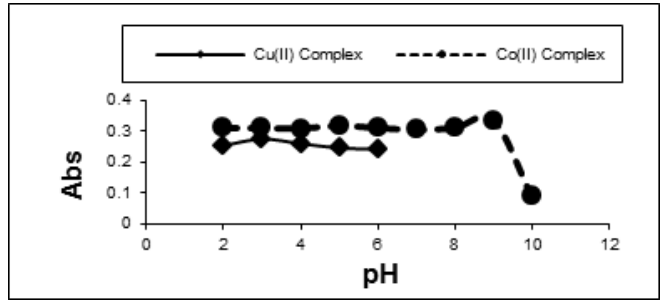

Fig( 4). Effect of $\mathrm{pH}$

\section{Effect of reaction time}

The color intensity reached a maximum after the $\mathrm{Co}$ (II) and $\mathrm{Cu}$ (II) has been reacted immediately with APAN therefore one minute development time was selected as optimum in the general procedure The color obtained were stable for a least $24 \mathrm{hr}$ for both complexes Fig(5).

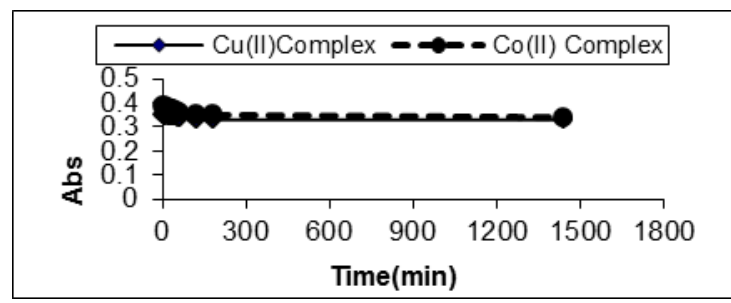

Fig( 5). effect of time 


\section{Effect of temperature}

The effect of temperature on the colour intensity of the products was studied . In practice, the same absorbance were obtained when the colour was developed at room temperature (2030) $\mathrm{C}^{\circ}$ complexes, but when the volumetric flask were placed in a water - bath for both at $(30-40) \mathrm{C}^{\circ}$ a loss in colour intensity and stability were observed, therefore it is recommended that the colour reactions should be carried out at room temperature for complexes Fig(6).

\section{Calibration graph}

The calibration equations for $(2-22$ $\mu \mathrm{g}$ per $10 \mathrm{ml} \quad 0.2-2.2 \mathrm{ppm}$ ) Co (II) and for $(2-24 \mu \mathrm{g}$ per $10 \mathrm{ml}, 0.2-2.4$ ppm) $\mathrm{Cu}$ (II) are $\mathrm{Y}=0.2482 \times+0.0002$ $(\mathrm{r}=0.9791) \quad \mathrm{y}=0.2122 \mathrm{x}+0.1153(\mathrm{r}=$ $0.9777)$ respectively. Since the coloured complexes are stable for 24 hrs, the method can be applied to large series of samples. The molar absorptivity and sandell sensitivity given in Table. 1

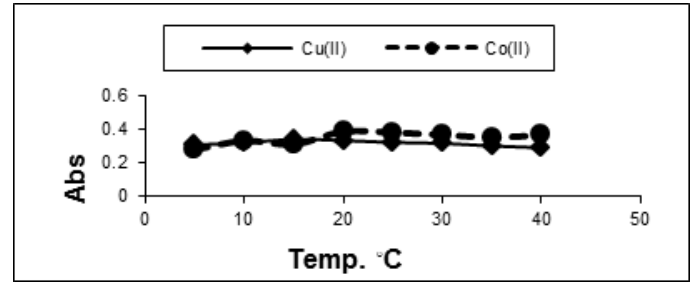

Fig(6.) Effect of temperature

\section{Conductivity measurements}

The solubility of the complexes in ethanol and DMSO permitted of the molar conductivity of $1 \times 10^{-3} \mathrm{M}$ solution at $25 \mathrm{C}^{\circ}$ and by comparison ,the electrolytic nature for complexes .The low values of molar conductance data listed in Table 2, indicate that the complexes are non electrolyte.

Table (2) :- Effect of Conductivity measurement

\begin{tabular}{|l||l|l|}
\hline \multicolumn{1}{|c|}{ Complexes } & \multicolumn{2}{c|}{$\begin{array}{c}\text { Conductivity measurements } \\
\text { S.mole }\end{array}$} \\
\cline { 2 - 3 } & \multicolumn{2}{|c|}{$\cdot \mathbf{c m}^{-2}$} \\
\hline $\mathrm{Co}(\mathrm{APAN})_{2} \cdot \mathrm{XH}_{2} \mathrm{O}$ & 10.3 & Ethanol \\
\hline $\mathrm{Cu}(\mathrm{APAN})_{2} \cdot \mathrm{XH}_{2} \mathrm{O}$ & 9.2 & 15.7 \\
\hline
\end{tabular}

\section{Composition of the complexes and free energy}

The composition of complexes were studied in the excess of reagent solution by the mole-ratio method . A break at a 1:2 (M:L) mole ratio suggested the formation of complexes where $\mathrm{M}=\mathrm{Co}(\mathrm{II}), \mathrm{Cu}(\mathrm{II})$ and $\mathrm{L}=$ APAN under the given condition. The formation constant of the reaction products was calculated according to the equation[12].Also the free energy changes $(\Delta G)$ were calculated according to the following equation; $\Delta \mathrm{G}=-2.303 \mathrm{RT} \log \mathrm{Kf}$ Where $\mathrm{R}=$ gas constant $=8.3 \mathrm{~J} /$ degree. mole, $\mathrm{T}=$ absolute temperature $={ }^{\circ} \mathrm{C}+273$. Using the above equation $\Delta \mathrm{G}$ were found to be -4953.8 KJ.mole ${ }^{-1}$ and -6673.3 respectively. The negative value of $\Delta \mathrm{G}$ indicates that the reactions are spontaneously. 


\section{IR Spectra of reagent and it s Complexes}

The I.R. bands of the (APAN) and its Co (II) and $\mathrm{Cu}(\mathrm{II})$ complexes with their probable assignment are give in Table .The IR Spectrum of the ligand shows abroad band at $3422 \mathrm{~cm}^{-1}$ , which can be attributed to the $v(\mathrm{OH})$ group. However, the $v(\mathrm{~N}=\mathrm{N})$ stretching band in the free ligand is observed at $1570 \mathrm{~cm}^{-1}$.This band is shifted to lower with low intensity $1565 \mathrm{~cm}^{-1}$ and $1560 \mathrm{~cm}^{-1}$ frequency values upon complexation suggesting chelation via the (M-N) [13-15] .The IR Spectrum of the ligand revealed a sharp band at $1643 \mathrm{~cm}^{-1}$ due to $v$ $(\mathrm{C}=\mathrm{N})$ of the $\mathrm{N}$ pyrozol azo nitrogen. The band of $(\mathrm{C}=\mathrm{O})$ is shifted to lower frequencies in the complexes indication to that it has been affected upon chelation to the metal ion[16] .The bonding of oxygen to the metal ion is provided by the occurrence of bands at $520-525 \mathrm{~cm}^{-1}$ as the result of $v(\mathrm{M}-\mathrm{O})[17]$.

Table( 3):- Selected IR data of (APAN) and its complexes with $\mathrm{Co}, \mathrm{Cu}(\mathrm{II})$.

\begin{tabular}{|c|c|c|c|c|c|c|c|}
\hline compound & $v(\mathrm{OH})$ & $v(\mathrm{C}=\mathrm{N})$ & $v(\mathrm{~N}=\mathrm{N})$ & $v(\mathrm{C}-\mathrm{O})$ & $v(\mathrm{M}-\mathrm{O})$ & $\begin{array}{c}v(\mathrm{C}-\mathrm{H}) \\
\text { Aromt }\end{array}$ & $\begin{array}{c}v(\mathrm{M}-\mathrm{N}) \\
\text { azo }\end{array}$ \\
\hline $\mathrm{HL}$ & $3422 \mathrm{~m}$ & $1643 \mathrm{~s}$ & $1570 \mathrm{~m}$ & $1115 \mathrm{~s}$ & - & $3045 \mathrm{~m}$ & - \\
{$\left[\mathrm{Cu}(\mathrm{HL})_{2}\right] \mathrm{xH}_{2} \mathrm{O}$} & $3320 \mathrm{~m}$ & $1530 \mathrm{~s}$ & $1565 \mathrm{~m}$ & $1110 \mathrm{~s}$ & $520 \mathrm{w}$ & $3030 \mathrm{~m}$ & $425 \mathrm{w}$ \\
{$\left[\mathrm{Co}(\mathrm{HL})_{2}\right] \mathrm{xH}_{2} \mathrm{O}$} & $3316 \mathrm{~m}$ & $1532 \mathrm{~s}$ & $1563 \mathrm{~m}$ & $1120 \mathrm{~s}$ & $525 \mathrm{w}$ & $3030 \mathrm{~m}$ & $430 \mathrm{w}$ \\
\hline
\end{tabular}

S: sharp, m: medium,w: weak On the basis of the IR, and a stoichiometric data the structure of complexes can be suggested as follows $\operatorname{Fig}(7)$

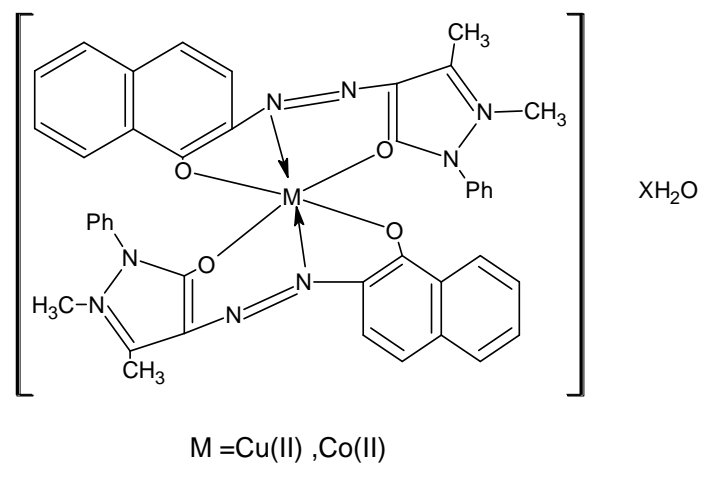

Fig (7):- The proposed structural formula of $\mathrm{Co}(\mathrm{II}) \& \mathrm{Cu}(\mathrm{II})$ complexes with APAN.

\section{Application}

The propose method ware applied to the determination of $\mathrm{Co}$ (II) and $\mathrm{Cu}(\mathrm{II})$ in synthetic mixture were analyzed by the procedures described above and results displayed in Table 3 . 
Table (4):- Determination of $\mathrm{Co}(\mathrm{II})$ and $\mathrm{Cu}(\mathrm{II})$ in synthetic mixtures

\begin{tabular}{|c|c|c|}
\hline $\begin{array}{c}\text { Composition of mixture } \\
\mu g . m I^{1}\end{array}$ & $\begin{array}{c}\text { Found by present } \\
\text { method } \mu g . m^{-1}\end{array}$ & $\begin{array}{c}\text { \%R.SD of the Co(II) and } \\
\text { Cu(II) complexes }\end{array}$ \\
\hline $\mathrm{Co}^{++}(1), \mathrm{Cu}^{++}(10), \mathrm{Fe}^{+++}(10)$ & 1.040 & 0.291 \\
\hline $\mathrm{Co}^{++}(0.8), \mathrm{Ni}^{++}(10), \mathrm{pd}^{++}(10)$ & 0.896 & 0.336 \\
\hline $\mathrm{Cu}^{++}\left(0.4 \mathrm{Co}^{++}(10) \mathrm{Mn}^{++}(10)\right.$ & 0.472 & 0.332 \\
\hline $\mathrm{Cu}^{++}(1), \mathrm{Cr}^{++}(10), \mathrm{Fe}^{+++}(10)$ & 0.623 & 0.985 \\
\hline
\end{tabular}

\section{Conclusion:}

4-(4-antipyriyl azo) -2-Naphthal react with $\mathrm{Cu}(\mathrm{II})$ and $\mathrm{Co}(\mathrm{II})$, which from complexes which can be easily dissolved in ethanolic solution. The present method has been found to be simple, rapid and applicable for the determination of $\mathrm{Cu}(\mathrm{II})$ and $\mathrm{Co}(\mathrm{II})$ metals in the presence of each other ,which makes it an alternative to the existing methods for the determination of these metals.

\section{References:}

1-P.Sarbani ;N. Tyotion and $\mathrm{S}$ .Nalla,J.Braz.chem.Soc. 2008.19(6).

2- Y. Azhar ; J. Hussain ,proceedings of The first Conference for pure and Applied seiences 2008

3- G .Shar; G. Soomro,The Nucleus .2004. 41:1-4.

4-P.Umangn ;S.Arun ,E-journal of chemistry .2009. 6(S1):S452-S458.

5-R.Kavita ;S. Ragivk and H.B. Singh, E-journal of chemistry 2010. 7(S1):566-572.
6-J.K.Suh; J.C.Woo and S.H.Lee, Anal.Sci,2001.17:231-234.

7-K.A.Wagner;R.M.Danied and D.Self.J.AotInt,84 20011934.

8-S.Luterotti and T.Vukman, Acta.Pharm,52 2002:143-148.

9-Zh.G.Zhu and G.X.Wang ,J.Chin,19 1999210.

10-M.Farukawa and S.Shibata,Anal chimActa140 1982301.

11-A.P.Gusack; N.B. Patal and J.P.Smith, Inorg. cheme,17 1987. 1023

12-N.EL-Enany; F. Bolal and K.Rizk.J.Chin.Chim.Soc 542007 941.

13-M.M.Omar; G. Mohamed, Spectro. Chim Acta.part A,61, 2005. 929.

14-G.Pandey ; K.K. Narng. Synt. Reas.Inorg.Metorg.chem,34. 2004 . 291.

15-G.G.Mohamed; M.A.Zayed and N.E.AL-Gamel, Spectro chim. Acta, 58, 2002. 3167.

16-K.A.Wagner,R. Mcdanid and D.Self.J.AOAC Int,84 2001. 1934.

17- Z.M.Zaki. spectrohim. Acta, 56 2000. 1917. 


\section{تخليق ودراسة طيفية للمركب Antipyryl azo 2-Naphthoo و واستخدامه ككاثف جديد لتحديد ايونات}

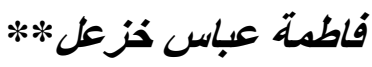

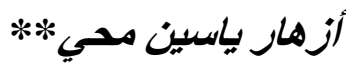

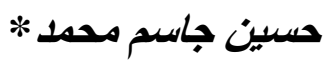

*كلية العلوم جامعة الكوفه

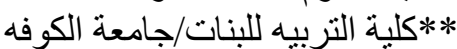

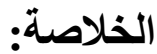

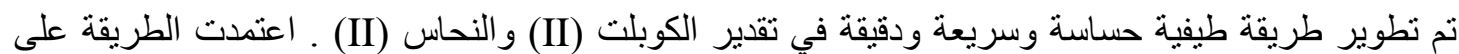

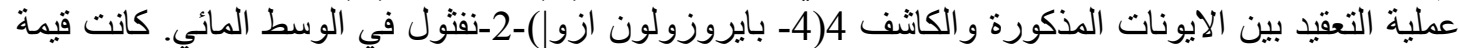

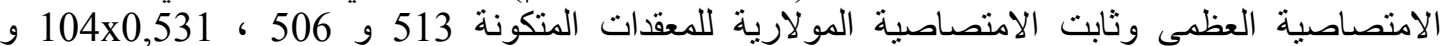

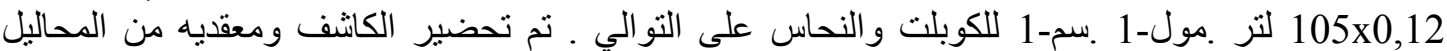

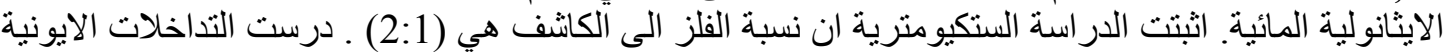

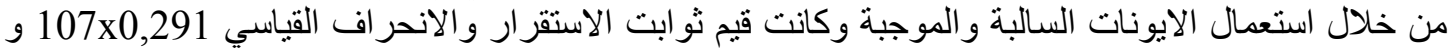

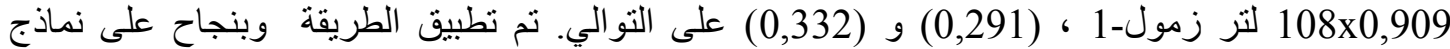

